\title{
Open trial of cyclosporine in patients with severe active Crohn's disease refractory to conventional therapy
}

\author{
Kevork M. Peltekian, C. Noel Williams, Allan S. MacDonald, \\ Peter D. Roy, Elizabeth CZOLPINSKa
}

\begin{abstract}
Fifteen patients with severe active Crohn's disease, refractory to conventional therapy, were given a 16 week course of cyclosporine at an initial oral daily dose of $10 \mathrm{mg} / \mathrm{kg}$, adjusted to maintain cyclosporine serum trough levels between 100 and $200 \mathrm{ng} / \mathrm{ml}$. Five patients withdrew early because of side effects, poor absorption or noncompliance. The remaining 10 patients all improved within four weeks as measured by three different clinical indices: Crohn's Disease Activity Index, Simple Index of Crohn's Disease Activity and Mean Score of Therapeutic Goals (MSTG). Seven patients maintained this initial improvement and prednisone was either reduced or discontinued. Four of these seven patients relapsed within four weeks of stopping cyclosporine, and three remain in remission after $75 \pm 2$ weeks. Side effects were minor and easily reversible. When the various clinical and laboratory indices were compared, MSTG was found to be the most useful index for the assessment of therapy. Cyclosporine appears to be a safe and effective therapy in patients with severe active Crohn's disease refractory to conventional therapy. Can J Gastroenterol 1988; 2(1): 5-11
\end{abstract}

Key Words: Crohn's disease, Cyclosporine, Immunosuppressive agents

Departments of Medicine and Surgery, Faculty of Medicine, Dalhousie University, and Victoria General Hospital, Halifax, Nova Scotia

Correspondence and reprints: Dr C.N. Williams, Clinical Research Centre, Room CD-1, Faculty of Medicine, Dalhousie University, 5849 University Avenue, Halifax, Nova Scotia $\mathrm{B} 3 \mathrm{H} 4 \mathrm{H} 7$

Presented in part during the May, 1987 Digestive Disease Week Annual Scientific Meeting of the American Gastroenterological Association in Chicago, Illinois and at the National Foundation for Ileitis and Colitis Symposium, October, 1987, Fort Lauderdale, Florida
PrOHn's DISEASE IS A CHRONIC relapsing inflammatory condition of the bowel characterized by chronic diarrhea, abdominal pain, weight loss, fistula formation and perineal complications. In acute exacerbations of the disease, treatment with corticosteroids is effective $(1,2)$. Treatment with 6-mercaptopurine is the only drug available for patients with chronically active, complicated disease who fail on corticosteroid therapy (3). After surgery, recurrence at the anastomosis occurs in all patients with time, with varying degrees of severity (4). Sulfasalazine has been shown to be effective, mainly when the disease involves the colon, but even then, maintenance therapy does not seem to prevent relapse $(1,5)$.

In recent years, 5-aminosalicylic acid, the therapeutic moiety of sulfasalazine, has been used in Crohn's disease (6). Except for elimination of 
side effects related to the reabsorption of the sulfapyridine portion of sulfasalazine, there is no evidence for a difference in efficacy between 5 -aminosalicylic acid and sulfasalazine (7). Metronidazole appears to be effective in patients with perineal disease (8) and equally effective as sulfasalazine in treatment of colonic Crohn's disease (9). Immunosuppressive agents, such as azathioprine, and its active metabolite 6-mercaptopurine, are useful in inducing remission and in allowing corticosteroid reduction or discontinuation in otherwise induced stable remission (3), and in healing fistulae (10). Azathioprine and 6-mercaptopurine have several drawbacks which limit their use: the required treatment time for induction of remission is prolonged and severe side effects (myelosuppression, hepatotoxicity, paricreatitis) have been reported $(11,12)$. This lack of definitive treatment has stimulated trials of new agents for treatment of Crohn's disease.

Cyclosporine, with its specific immunomedulatory action (13-15) and its efficacy and relative safety in comparison to other immunosuppressive agents, particularly in organ transplantation $(15,16)$, and its effective prevention of autoimmunity in animal models $(17,18)$, has prompted its experimental use in a series of autoimmune diseases in man (19), including Crohn's disease. Preliminary studies with Crohn's disease have been encouraging (20-22).

This study describes the effects of cyclosporine and its apparent safety in an open study in patients with severe active Crohn's disease who were refractory to conventional therapy.

\section{MATERIALS AND METHODS}

Patients: Since October 1985, patients with severe active Crohn's disease diagnosed according to clinical, radiologic, endoscopic and histologic criteria (2) who were refractory to conventional therapy were offered cyclosporine. The exclusion criteria included renal failure, severe hepatocellular disease, pregnancy or inadequate contraception, malignancy, impending surgery, continuous gastrointes- tinal bleeding, intake of nephrotoxic compounds or drugs affecting cyclosporine metabolism.

Fifteen patients (five men and 10 women) were enrolled into the open trial. The mean age was 42 years (range 20 to 67 ). The mean duration of illness since diagnosis was nine years (range 0.5 to 28). All patients had continuous symptoms of active Crohn's disease for a mean duration of seven months (range one to 15) at entry. Nine of the 15 patients had undergone abdominal surgery during the course of their illness. In five patients the disease was confined to the terminal ileum, and in one to the rectum, the remaining nine had disease in their ileum and colon (Table 1). The trial protocol was approved by the Victoria General Hospital Research Review Committee. Fully informed, written consent was obtained from all patients. Oral cyclosporine (Sandimmune) was supplied by Sandoz Canada Inc, Dorval, Quebec.

Design: The initial cyclosporine dosage was $10 \mathrm{mg} / \mathrm{kg}$ given twice daily, adjusted, thereafter, to maintain

TABLE 1

Summary of data on 15 patients with Crohn's disease at entry to cyclosporine trial with their course and final outcome

\begin{tabular}{|c|c|c|c|c|c|c|c|c|}
\hline Patient & $\begin{array}{l}\text { Sex, } \\
\text { age (years) }\end{array}$ & $\begin{array}{l}\text { Duration } \\
\text { of } \\
\text { illness } \\
\text { (years) }\end{array}$ & $\begin{array}{l}\text { Duration } \\
\text { of } \\
\text { activity } \\
\text { (months) }\end{array}$ & Prior surgery & CDAI & $\begin{array}{l}\text { Site of } \\
\text { disease }\end{array}$ & $\begin{array}{l}\text { Other } \\
\text { treatment } \\
\text { (daily dose) }\end{array}$ & Course and final outcome \\
\hline 1 & $F, 67$ & 14 & 6 & None & 360 & $\begin{array}{l}\text { Ileocolitis, } \\
\text { enteroenteral } \\
\text { fistula }\end{array}$ & $\begin{array}{l}\text { Pred }(25 \mathrm{mg}) \\
\text { •Aza } 100 \mathrm{mg}) \\
\text { Sulfa }(4 \mathrm{~g})\end{array}$ & $\begin{array}{l}\text { Pred discontinued; relapse } 4 \\
\text { weeks after stopping CyA }\end{array}$ \\
\hline 2 & $F, 56$ & 21 & 2 & $\begin{array}{l}\text { Total colectomy, } \\
\text { ileostomy }\end{array}$ & 345 & $\begin{array}{l}\text { lleitis, } \\
\text { enterocutaneous } \\
\text { fistula }\end{array}$ & $\begin{array}{l}\text { Pred }(25 \mathrm{mg}) \\
\text { TPN }\end{array}$ & $\begin{array}{l}\text { Started on iv CyA because of } \\
\text { short bowel syndrome; dose } \\
\text { was doubled after undetectable } \\
\text { CyA serum trough levels; acute } \\
\text { threefold rise in creatine } \\
\text { resulted in stopping CyA in } \\
\text { week } 2\end{array}$ \\
\hline 3 & $F, 55$ & 7 & 2 & $\begin{array}{l}\text { Right hemicolectomy, } \\
\text { multiple small } \\
\text { bowel and } \\
\text { sigmoid resections }\end{array}$ & 397 & $\begin{array}{l}\text { lleocolitis } \\
\text { enteroenteral } \\
\text { fistula }\end{array}$ & Nonet & $\begin{array}{l}\text { CyA serum trough level } \\
\text { remained undetectable after } \\
\text { fourfold increase in CyA dose } \\
\text { by week } 4 \text {; iv CyA was } \\
\text { initiated, but patient's condition } \\
\text { had worsened warranting } \\
\text { surgery. }\end{array}$ \\
\hline 4 & $F, 20$ & 3 & 4 & None & 413 & Ileocolitis & $\begin{array}{l}\text { Pred }(60 \mathrm{mg}) \\
\text { TPN }\end{array}$ & $\begin{array}{l}\text { After initial improvement and } \\
\text { reduction of pred to } 10 \mathrm{mg} \text {, } \\
\text { relapsed in week } 10 \text { of CyA } \\
\text { trial }\end{array}$ \\
\hline
\end{tabular}


TABLE 1 continued

\begin{tabular}{|c|c|c|c|c|c|c|c|c|}
\hline 5 & $F, 37$ & 13 & 10 & $\begin{array}{l}\text { Right hemicolectomy, } \\
\text { small bowel } \\
\text { resection }\end{array}$ & 328 & Neitis & Pred $(40 \mathrm{mg}$ ) & $\begin{array}{l}\text { Pred reduced to } 10 \mathrm{mg} \text {; in } \\
\text { remission } 78 \text { weeks after } \\
\text { stopping CyA }\end{array}$ \\
\hline 6 & $F, 41$ & 5 & 4 & $\begin{array}{l}\text { Right hemicolectomy, } \\
\text { terminal ileal } \\
\text { resection }\end{array}$ & 429 & Ileocolitis & $\begin{array}{l}\text { Pred }(35 \mathrm{mg}) \\
\text { •Aza ( } 25 \mathrm{mg}) \\
\text { Sulfa }(2 \mathrm{~g})\end{array}$ & $\begin{array}{l}\text { Pred discontinued; in remission } \\
78 \text { weeks after stopping CVA }\end{array}$ \\
\hline 7 & $F .25$ & 0.5 & 6 & $\begin{array}{l}\text { Partial cecotomy. } \\
\text { terminal ileal } \\
\text { resection }\end{array}$ & 295 & Neitis & None & $\begin{array}{l}\text { Although improving; withdrew } \\
\text { for noncompliance in week } 4 \text { of } \\
\text { CyA trial }\end{array}$ \\
\hline 8 & $F, 25$ & 9 & 10 & $\begin{array}{l}\text { Subtotal colectomy, } \\
\text { ileostomy }\end{array}$ & 216 & $\begin{array}{l}\text { Perineal } \\
\text { fistula }\end{array}$ & None & $\begin{array}{l}\text { After initial improvement, } \\
\text { relapsed in week } 12 \text { of CyA } \\
\text { trial; later had rectal stump } \\
\text { resected }\end{array}$ \\
\hline 9 & $M, 34$ & 8 & 2 & None & 307 & Ileocolitis & $\begin{array}{l}\text { Pred }(20 \mathrm{mg}) \\
\text {-Aza (100 mg) }\end{array}$ & $\begin{array}{l}\text { Pred discontinued; relapsed } 2 \\
\text { weeks after stopping CyA }\end{array}$ \\
\hline 10 & $F, 63$ & 3 & 10 & $\begin{array}{l}\text { Right hemicolectomy, } \\
\text { terminal ileal } \\
\text { resection }\end{array}$ & 371 & Ileitis & $\begin{array}{l}5-A S A \\
(1.2 \mathrm{~g})\end{array}$ & $\begin{array}{l}\text { In remission } 70 \text { weeks after } \\
\text { stopping CyA }\end{array}$ \\
\hline 11 & $M, 53$ & 28 & 13 & $\begin{array}{l}\text { Terminal ileal } \\
\text { resection }\end{array}$ & 282 & lleitis & Pred (20 mg) & $\begin{array}{l}\text { Withdrew in week } 2 \text { of CyA } \\
\text { trial because of gastrointestinal } \\
\text { intolerance }\end{array}$ \\
\hline 12 & $M, 45$ & 8 & 1 & None & 224 & Ileitis & Pred (20 mg) & $\begin{array}{l}\text { Withdrew in week } 4 \text { of CyA } \\
\text { trial because of gastrointestinal } \\
\text { intolerance }\end{array}$ \\
\hline 13 & M.26 & 3 & 15 & None & 160 & Heocolitis & $\begin{array}{l}\text { Pred }(40 \mathrm{mg}) \\
\text { Sulfa }(2 \mathrm{~g}) \\
\text { Metr }(750 \mathrm{mg})\end{array}$ & $\begin{array}{l}\text { Pred reduced to } 10 \mathrm{mg} \text {; } \\
\text { relapsed } 4 \text { weeks after stopping } \\
\text { CyA }\end{array}$ \\
\hline 14 & $M, 52$ & 4 & 10 & None & 338 & Heocolitis & Pred $(10 \mathrm{mg})$ & $\begin{array}{l}\text { Pred discontinued; relapsed } 2 \\
\text { weeks after stopping CyA }\end{array}$ \\
\hline 15 & $F, 34$ & 14 & 12 & $\begin{array}{l}\text { Right hemicolectomy, } \\
\text { small bowel and } \\
\text { later ileocolic } \\
\text { anastomosis } \\
\text { resections }\end{array}$ & 160 & Heocolitis & $\begin{array}{l}\text { Sulfa }(3 \mathrm{~g}) \\
\text { Bet }(5 \mathrm{mg})\end{array}$ & $\begin{array}{l}\text { After initial improvement, } \\
\text { relapsed in week } 12 \text { of CyA } \\
\text { trial; was started on TPN and } \\
\text { Pred ( } 40 \mathrm{mg} \text { ) }\end{array}$ \\
\hline
\end{tabular}

- Treatment was discontinued at entry to cyclosporine trial; + Severe prior side effects to prednisone; CDAl Crohn's Disease Activity Index, Aza Azathioprine; Bet Betamethasone enema; CyA Cyclosporine; Metr Metronidazole; Pred Prednisone; Sulfa Sulfasalazine; TPN Total parenteral nutrition: 5 -ASA 5 -acetylsalicylic acid; iv Intravenous

serum trough levels of cyclosporine between 100 and $200 \mathrm{ng} / \mathrm{ml}$, measured $11 \mathrm{~h}$ after the previous dose. Patient 2 , who was on home total parenteral nutrition program because of short bowel syndrome after multiple intestinal resections, was started on intravenous cyclosporine at a daily dose of $2.5 \mathrm{mg} /$ kg. Blood samples for serum cyclosporine level were taken twice a week, where necessary. All levels were determined by radioimmunoassay using the Cyclosporine RIA-Kit (Sandoz, Basle, Switzerland). In 10 patients cyclosporine was initiated on an outpatient basis.

From the start of the study, prednisone dose reduction at a rate of 2.5 to $5.0 \mathrm{mg} /$ week was attempted.
Azathioprine was discontinued prior to starting cyclosporine. Sulfasalazine, 5-aminosalicylic acid and metronidazole were maintained throughout the trial period. Cyclosporine was administered for 16 weeks at the end of which it was discontinued without tapering. The 16 week period was chosen following the design and results of previous Crohn's disease studies $(1,23)$ and because of the known reversibility of renal side effects after short term use of cyclosporine $(24,25)$. Patients were seen regularly during and after cyclosporine therapy and their Crohn's disease course to relapse documented.

Assessment: Patients were seen at entry, then at two, four, eight, 12 and 16 weeks for overall clinical assessment and the measurement of disease activity by three clinical indices: Crohn's Disease Activity Index (CDAI) $(26,27)$; Simple Index of Crohn's Disease Activity (SICDA) (28); and Mean Score of Therapeutic Goals (MSTG). Since its publication in 1976, CDAI has become a standard for the quantitative assessment of efficacy in clinical trials of therapy for Crohn's disease. Ars inconvenient problem inherent in the CDAI is the need to collect data for seven days before patient enrollment $(28,29)$. This lead to the development of a simplified version, the SICDA. However, both are considered to be relatively unsatisfactory because they depend on many subjective criteria 
(30). The authors' main criticism of these indices is their heavy reliance on the number of bowel movements without consideration for the presence or extent of previous intestinal resections. Neither the CDAI nor the SICDA takes into account a factor for a therapeutic drug effect in Crohn's disease. Consequently, a patient may be considered in remission when the CDAI is less than 150 even when the patient requires a high maintenance dose of corticosteroids. A further limitation is the weighting CDAI places on hemoglobin level - a problem in cyclosporine studies because of the known propensity of this drug to induce a reversible drop in hemoglobin between 2 and $4 \mathrm{~g} / \mathrm{dL}$ (24).

Therefore, the authors modified and adapted a grading system, dependent on the setting of individual therapeutic goals similar to the one used in the study of 6-mercaptopurine for Crohn's disease (3). These therapeutic goals were categorized into four items: wellbeing (weight, appetite, sense of well- being); symptoms and signs (diarrhea, fever, mass, pain, tenderness); corticosteroids (dose-raising, dose-lowering or introducing); and other complications (activity of fistulae, extraintestinal manifestations).

At entry, depending on the clinical presentation of each patient, two to four therapeutic goal items were chosen and an initial score of zero given for each item in all patients. The degree of improvement or worsening for each item was graded using a scale from +3 for complete disappearance of symptoms or signs (or total withdrawal from corticosteroids); +2 for substantial symptom or sign alleviation short of $100 \%$; +1 for any slight but already discernible symptomatic improvement; 0 for no change; -1 for slight symptomatic worsening; -2 for moderate symptomatic worsening; -3 for severe complications (or resumption of prednisone at a dose of $40 \mathrm{mg} /$ day or higher). The MSTG was the arithmetic mean of the scores of all the therapeutic goal items graded for each in-

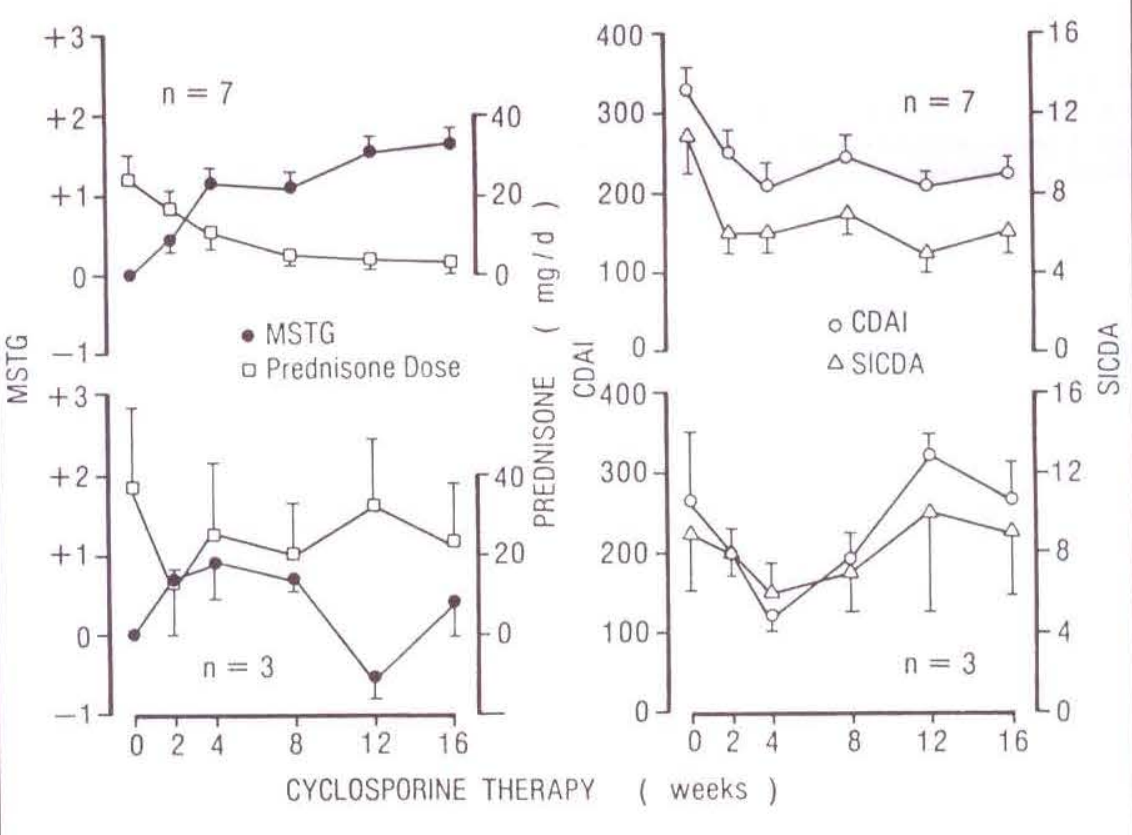

Figure 1) Crohn's disease activity and prednisone dose (mean \pm SEM) in the 10 patients that completed the 16 week course of cyclosporine therapy. By week 4, all 10 patients improved by the three clinical indices measured in this trial: Mean Score of Therapeutic Goals (MSTG), Crohn's Disease Activity Index (CDAI), and Simple Index of Crohn's Disease Activity (SICDA); however, only seven maintained this initial improvement (upper panel) while tapering off prednisone, and three relapsed (lower panel) on cyclosporine terval. At the end of the 16 week period patients with positive MSTG were considered improved.

Blood samples were taken biweekly for monitoring of Crohn's disease activity and side effects of therapy. Blood samples were evaluated for complete blood count, erythrocyte sedimentation rate (ESR), C-reactive protein, orosomucoid, creatinine, liver functions and other routine serum biochemical tests. At least twice during the 16 week period reticulocyte count, vitamin B12, ferritin, serum and erythrocyte folate levels were also determined.

The side effects were either reported by the patient, or sought by the examiner, and recorded according to severity as slight, moderate or severe (requiring discontinuation of therapy). The cyclosporine dose was reduced by 25 to $50 \%$ when serum creatinine rose more than 50 to $75 \%$ above pretreatment value or above $150 \mu \mathrm{mol} / \mathrm{L}$.

Statistical analysis was performed using the Wilcoxon matched-pairs signed-ranks test with a significance level of 0.05 or less (two-tailed). All results are given as mean \pm SEM.

\section{RESULTS}

Table 1 summarizes the data for patients at entry to the trial with their course and outcome. All nonoperated patients who tolerated cyclosporine came into remission and all relapsed within eight weeks after discontinuing the 16 week course of medication. In contrast, of those with recurrent disease after surgery, three patients were in remission after one year of followup. They had four to 10 months of continuous active disease at entry to this study.

Five patients withdrew early in the course of the trial, three because of side effects related to cyclosporine therapy, one because of poor absorption of the drug and one noncompliance.

All 10 patients who completed 16 weeks of cyclosporine therapy improved significantly within the first four weeks by all criteria. MSTG increased from a score of zero at entry to $+1.1 \pm 0.2$ after four weeks of cyclosporine therapy $(\mathrm{P}<0.01)$; CDAI 
TABLE 2

Outcome of all 15 patients who entered cyclosporine trial $59 \pm 3$ weeks after stopping cyclosporine

\begin{tabular}{lccc}
\hline & \multicolumn{2}{c}{$\begin{array}{c}\text { Completed 16 week } \\
\text { Course }\end{array}$} & Drop-outs \\
& Improved & Relapsed & \\
\hline Number of patients & 7 & 3 & 5 \\
In remission, no corticosteroids & 3 & - & - \\
Required abdominal surgery & 1 & 2 & 2 \\
On home total parenteral nutrition & - & - & 3 \\
Corticosteroid-dependent & 3 & - \\
\hline
\end{tabular}

dropped from $308 \pm 31$ at entry to 109 $\pm 26(\mathrm{P}<0.01) ;$ and SICDA dropped from $10 \pm 1$ to $6 \pm 1(\mathrm{P}<0.01)$. In addition, prednisone dose was reduced from $28 \pm 7 \mathrm{mg} /$ day at entry to $16 \pm 6$ $\mathrm{mg} /$ day by the end of week $4(\mathrm{P}<0.01)$.

Seven of the 10 patients maintained their improvement throughout the 16 week trial period (Figure 1). Prednisone was discontinued in four of these seven patients and reduced to $10 \mathrm{mg}$ in two patients within $9 \pm 1$ weeks of starting cyclosporine therapy. The remaining three patients became worse around week 12 . In two of the three patients this was related to reduction in prednisone dose. All three completed the trial period with disease activity returning to pretreatment levels.

Within four weeks of stopping cyclosporine, four of the seven patients relapsed, with indices returning to pretreatment levels. As of January 1988 three patients remain in remission, 59 \pm 3 weeks after stopping cyclosporine. The outcome, by the end of January 1988, for all 15 patients who entered the trial is summarized in Table 2.

Table 3 shows the partial correlation coefficients between the clinical and laboratory indices used in this trial. The MSTG correlated well with CDAI and SICDA. When MSTG was compared to the laboratory indices, only orosomucoid correlated slightly with MSTG. The equations for the linear relation between the different clinical indices were derived: $\mathrm{CDAI}=326-$ $73 \times(\mathrm{MSTG}) ;$ SICDA $=8.4-2.5 \times$ $(\mathrm{MSTG}) ;$ and $\mathrm{CDAI}=124+21 \times$ (SICDA).

Side effects: Table 4 lists side effects noted by the 15 patients entering the trial. In general, these side effects were not severe enough to warrant discontinuation of cyclosporine except for epigastric pain or nausea which contributed to withdrawal by two patients. Three of the 15 patients had a 'flu-like syndrome that cleared spontaneously. There was a rise in creatinine and urea nitrogen in almost all patients; in one patient therapy was withdrawn, and in three patients the dose of cyclosporine was reduced by more than $25 \%$. Renal function returned to pretreatment ranges after reduction or discontinuation of the

\section{TABLE 3}

Partial correlation coefficient of various clinical and laboratory indices

\begin{tabular}{lcc}
\hline & MSTG & CDAI \\
\hline CDAI & $-0.67^{\cdots} \cdots$ & \\
SICDA & $(n=72)$ & \\
Orosomucoid & $-0.57^{\cdots} \cdots$ & $+0.81^{\cdots} \cdots$ \\
Creactive protein & $(n=72)$ & $(n=95)$ \\
Erythrocyte sedimentation rate & $-0.35^{*}$ & $+0.31^{\circ}$ \\
& $(n=42)$ & $(n=58)$ \\
& -0.26 & $+0.33^{\cdots}$ \\
& $(n=68)$ & $(n=90)$ \\
& +0.05 & +0.18 \\
& $(n=67)$ & $(n=89)$ \\
\hline
\end{tabular}

MSTG Mean Score of Therapeutic Goals; CDAI Crohn's Disease Activity Index; SICDA Simple Index of Crohn's Disease Activity: $n$ Number of occasions where the indices were measured in the 15 patients who entered the cyclosporine trial. $\cdots p<0.001, \cdots p<0.01 ; \cdot p<0.05$ drug. Mild hyperuricemia in eight patients and borderline hyperkalemia in three patients were noted. There was a transient mild increase in the blood pressure of three patients who were borderline hypertensives before the initiation of cyclosporine. Hepatic toxicity was noted in only one patient whose serum transaminases rose sixfold, returning to normal after the dose of cyclosporine was reduced by $25 \%$.

\section{TABLE 4}

Symptomatic side effects of cyclosporine in 15 patients who entered the trial

\begin{tabular}{lc}
\hline Side effect & $\begin{array}{c}\text { Number of } \\
\text { patients }\end{array}$ \\
\hline Paresthesia/hyperesthesia & 9 \\
Epigastric burning/nausea & $8^{*}$ \\
Tremor & 8 \\
Hypertrichosis & 7 \\
Ariorexia & 3 \\
Fatigue & 2 \\
Gingival hypertrophy & 2 \\
Breast tenderness & 1 \\
Mild depression & 1 \\
\hline
\end{tabular}

- Caused two patients to drop out of the study

A mean drop of $1.4 \pm 0.4 \mathrm{~g} / \mathrm{dL}$ in hemoglobin $(\mathrm{P}<0.01)$ with no change in percentage reticulocyte count (2.0 $\pm 0.3 \%$ ) occurred in all patients who completed the 16 week therapy. This drop in hemoglobin was characterized by normochromic, normocytic changes. There was a trend towards an increase in ESR, C-reactive protein and platelet count in cyclosporinetreated patients, which did not reach statistical significance. In the seven patients who improved clinically ESR increased from $30 \pm 11$ to $46 \pm 12 \mathrm{~mm} /$ h, C-reactive protein rose from $0.9 \pm$ 0.5 to $1.5 \pm 0.6 \mathrm{mg} / \mathrm{dL}$, and platelet count increased from $375,000 \pm$ 53,000 to $411,000 \pm 65,000 / \mu \mathrm{L}$ (all nonsignificant changes).

\section{DISCUSSION}

The failure to isolate an infectious agent, and the favourable response of Crohn's disease to corticosteroids and 6-mercaptopurine suggests that immunological mechanisms play a role in the initiation and/or perpetuation of tis- 
sue damage in the disorder. Considerable evidence points to the sensitization of circulating $T$ lymphocytes to certain intestinal-and/or bacterial-related antigens (31), with reduction of suppressor $T$ lymphocyte function in severe active Crohn's disease (32). Cyclosporine may reverse this process by selectively inhibiting helper $\mathrm{T}$ lymphocyte production of interleukin2 essential for B lymphocyte and cytotoxic $T$ lymphocyte differentiation and proliferation, while allowing the expansion of suppressor T lymphocyte populations (16).

The group of patients that completed this open trial of cyclosporine had severe active Crohn's desease as evidenced by CDAI of $308 \pm 85$ ( \pm $\mathrm{SE})$, worse than patients entering previous major Crohn's disease studies: the US National Cooperative (CDAI of $245.7 \pm 70.1)(1)$, and the European Cooperative (CDAI of $176.5 \pm 98.4$ ) (2). In addition, the present patients were symptomatic despite conventional therapy.

There was an initial improvement in 10 of the 15 patients $(67 \%)$ who entered the trial, within four weeks of starting cyclosporine treatment. Some of the patients, though improved, did not achieve CDAI of less than or equal to 150 , which was chosen as the limiting value to consider patients in 'remission' in previous studies $(1,2)$. However, in the original group of patients on whom the development of CDAI was based (23), $10 \%$ of patients considered clinically 'very well' and $69 \%$ considered clinically 'fair to good', had CDAI greater than 150. In this trial, after a 16 week course of cyclosporine, seven patients achieved a significant 105 unit improvement on the CDAI scale $(\mathrm{P}<0.05)$ (Figure 1); this increases to 134 units if the 'hematocrit' item is not considered in the measurement of CDAI. A mild reversible drop in hemoglobin is a constant feature in all patients treated with cyclosporine, irrespective of clinical response.

Unlike 6-mercaptopurine, where the mean onset of response was 3.1 months (3), the effect of cyclosporine was evident within four weeks. In 10 patients that completed the trial, $70 \%$ maintained the initial improvement throughout the 16 week course.

In the present study it was possible to discontinue or reduce prednisone in a relatively short period, when previous attempts before entering the trial had failed. However, within four weeks of stopping cyclosporine, there was relapse in four of seven patients $(57 \%)$ that had maintained the improvement through the 16 week period. In retrospect, the authors probably should not have been so aggressive in tapering or discontinuing prednisone dose in these patients, based on their clinical response. Perhaps there would have been less relapses at week 12 and later during the post treatment followup period if the prednisone dose was stable for at least four weeks.

Undesirable side effects of cyclosporine were relatively minor and reversible upon reduction or discontinuation of the drug. These were similar to those described previously $(24,33)$. Renal toxicity was minimized by regular monitoring of serum creatinine and cyclosporine trough levels with dose adjustment where necessary. No long term side effects were noted.

The daily dose of cyclosporine was carefully titrated, based on the trough levels, making no attempt to find the minimum effective dose. Based on the present study, a six to eight week course of cyclosporine may be as effective as the planned 16 week course.

The clinical assessment of activity for Crohn's disease is controversial. The present study compared the various clinical and laboratory indices in the same group of patients. MSTG was the most useful in the assessment of Crohn's disease activity before and after treatment. This index correlated well with the currently established indices and to a lesser extent with the laboratory indices. Obviously, the effects of cyclosporine on ESR (24) and $\mathrm{C}$-reactive protein make these tests unsatisfactory for assessing disease activity. Orosomucoid was, apparently, not affected by cyclosporine therapy. Of the laboratory indices, orosomucoid correlated best with the clinical assessment of Crohn's disease activity. These observations need to be con- firmed, and considered before incorporating any of the laboratory indices to a practical clinical index of Crohn's disease activity as has been suggested (30).

Cyclosporine appeared to have a therapeutic value in patients with severe active Crohn's disease refractory to conventional therapy. Side effects were minor and easily reversible. This apparent benefit and safety of cyclosporine in selected patients with Crohn's disease ideally needs to be confirmed by placebo-controlled, double-blind clinical trials. However, a controlled trial of 6-mercaptopurine versus cyclosporine may be ethically more acceptable with the disadvantage of very large numbers of patient enrollment to control for the $B$ error.

ACKNOWLEDGEMENTS: We thank Dr B. Garner and Mr J. Fahey, Department of Biostatistics, Faculty of Medicine, Dalhousie University, for their assistance in the statistical analysis, also Sandoz Canada Inc, Dorval, Quebec for supporting this study and supplying cyclosporine (Sandimmune).

\section{REFERENCES}

1.Summers RW, Switz DM, Sessions JT Jr, et al. National Cooperative Crohn's Disease Study: results of drug treatment. Gastroenterology 1979; 77: 847-69.

2. Malchow H, Ewe K, Brandes JW, et al. European National Cooperative

Crohn's Disease Study: results of drug treatment. Gastroenterology 1984; 86: 249-66.

3. Present DH, Korelitz Bl, Wisch N, Glass JL, Sachar DB, Pasternack BS.

Treatment of Crohn's disease with 6-mercaptopurine: a long-term, randomized, double-blind study. N Engl J Med 1980; 302: 981-7.

4. Lee EC, Papaioannou N. Recurrences following surgery for Crohn's disease. Clin Gastroenterol 1980; 9: 419-38.

5. Anthonisen P, Barany F, Folkenborg $\mathrm{O}$, et al. The clinical effect of salazosulphapyridine (Salazopyrin) in Crohn's disease: a controlled doubleblind study. Scand J Gastroenterol 1974; 9: 549-54.

6. Rasmussen SN, Binder V, Maier K, et al. Treatment of Crohn's disease with peroral 5-aminosalicylic acid. Gastroenterology 1983; 85: 1350-3. 
7. Maier K, Fruhmorgen P, Bode JC, Heller T, von Gaisberg U, Klotz U. Erfolgreiche Akutbehandlung chronisch-entzundlicher Darmerkrankungen mit oraler 5-Aminosalicylsaure. Dtsch Med Wochenschr 1985; 110: 363-8.

8. Bernstein LH, Frank MS, Brandt LJ, et al. Healing of perineal Crohn's disease with metronidazole. Gastroenterology 1980; 79: 357-65.

9. Ursing B, Alm T, Barany F, et al. A comparative study of metronidazole and sulfasalazine for active Crohn's disease: the Cooperative Crohn's Disease Study in Sweden II result. Gastroenterology 1982; 83: 550-62.

10. Korelitz BI, Present DH. Favorable effect of 6-mercaptopurine on fistulae of Crohn's disease. Dig Dis Sci 1985; 30: $58-64$.

11.Present DH, Meltzer SJ, Wolke A, Korelitz BI. Short and long-term toxicity to 6-mercaptopurine in the management of inflammatory bowel disease. Gastroenterology 1985; 88: 5,2,1545.

12. Haber C], Meltzer S], Present DH, Korelitz BI. Nature and course of pancreatitis caused by 6-mercaptopurine in the treatment of inflammatory bowel disease. Gastroenterology 1986; 91: 982-6.

13. White DJ, Plumb AM, Pawelec G, Brons 3. Cyclosporin A: an immunosuppressive agent preferentially active against proliferating $T$ cells. Transplantation $1979 ; 27$ : 55-8.

14. Janco RL, English D. Cyclosporine and human neutrophil function.
Transplantation 1983; 35: 501-3.

15. Kahan BD. Cyclosporine: the agent and its action. Transplant Proc 1985; 17 (Suppl 1): 5-19.

16. Cohen DJ, Loertscher R, Rubin MF, Tilney NL, Carpenter CB, Strom TB. Cyclosporine: a new immunosuppressive agent for organ transplantation. Ann Intern Med 1984; 101: 667-82.

17. Laupacis A, Stiller CR, Gardell C, et al. Cyclosporin prevents diabetes in BB Wistar rats. Lancet 1983; i: 10-2.

18. Nussenblatt RB, Rodriguez MM, Wacker WB, Cevario SJ, SalinasCarmona MC, Gery I. Inhibition of experimental autoimmune uveitis in Lewis rats. J Clin Invest 1981; 67: 1228-31.

19. ANON. Cyclosporin in autoimmune disease. Lancet 1985; i: 909-11. (Editorial)

20. Allison MC, Pounder RE. Cyclosporin for Crohn's disease. Lancet 1984; i: 902-3.

21. Bianchi PA, Mindelli M, Quarto di Palo F, Ranzi T. Cyclosporin for Crohn's disease. Lancet 1984; ii: 1242.

22. Dannecker G, Malchow H, Niessen KH, Ranke MB. Morbus Crohn: erste Erfahrungen mit Cyclosporin A bei einer Adoleszenten. Dtsch Med Wochenschr 1985; 110: 339-43.

23. Winship DH, Summers RW, Singleton JW, et al. National Cooperative Crohn's Disease Study: study design and conduct of the study. Gastroenterology 1979; 77: 829-42.

24. Palestine AG, Nussenblatt RB, Chan C.C. Side effects of systemic cyclosporine in patients not under- going transplantation. Am J Med $1984 ; 77: 652-6$.

25. Klintmalm GBG, lwatsuki S, Starzl TE. Nephrotoxicity of cyclosporine $\mathrm{A}$ in liver and kidney transplant patients. Lancet 1981;i: 470-1.

26. Best WR, Becktel JM, Singleton JW, Kern F Jr. Development of a Crohn's disease activity index.

Gastroenterology 1976; 70: 439-44.

27. Best WR, Becktel JM, Singleton JW. Rederived values of the eight coefficients of the Crohn's Disease Activi. ty Index (CDAI). Gastroenterology $1979 ; 77: 843-6$.

28. Harvey RF, Bradshaw JM. A simple index of Crohn's disease activity. Lancet 1980; i: 514.

29. Mee AS, Brown DJ, Jewell DP. Crohn's disease activity index - is it useful? Gut 1978; 19: 990.

30. Andre C, Descos L, Landais P, Fermanian J. Assessment of appropriate laboratory measurements to supplement the Crohn's disease activity index. Gut 1981; 22: 571-4.

31. Kirsner JB, Shorter RG. Recent developments in nonspecific inflammatory bowel disease. N Engl J Med 1982; 306: 837-48.

32. Hodgson HJF, Wands JR, Isselbacher KJ. Decreased suppressor cell activity in inflammatory bowel disease. Clin Exp Immunol 1978; 32: 451-8.

33. Feutren G, Papoz L, Assan R, et al. Cyclosporin increases the rate and length of remissions in insulin-dependent diabetes of recent onset: results of a multicentre double-blind trial. Lancet 1986; ii: 119-24.

\section{Clinical Quiz}

Please note, there may be more answers than asked for in the question.

\section{STOMACH}

1. What are the four different phases of gastric acid secretion?

What probable mechanisms of control may be operational for each of these phases?

2. In patients with high, low and variable acid secretion, name eight causes of hypergastrinemia. (Answers page 34)

\section{PANCREAS}

1. Certain clinical or laboratory features obtained at admission or during the initial $48 \mathrm{~h}$ of hospitalization correlate with severe or complicated course and increased mortality risk in acute ethanol-associated pancreatitis: Give eight of these features.

2. List eight complications of cystic fibrosis on the gut, liver and pancreas.

(Answers page 34) 


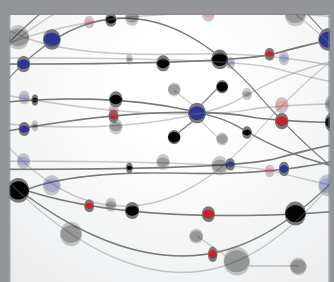

The Scientific World Journal
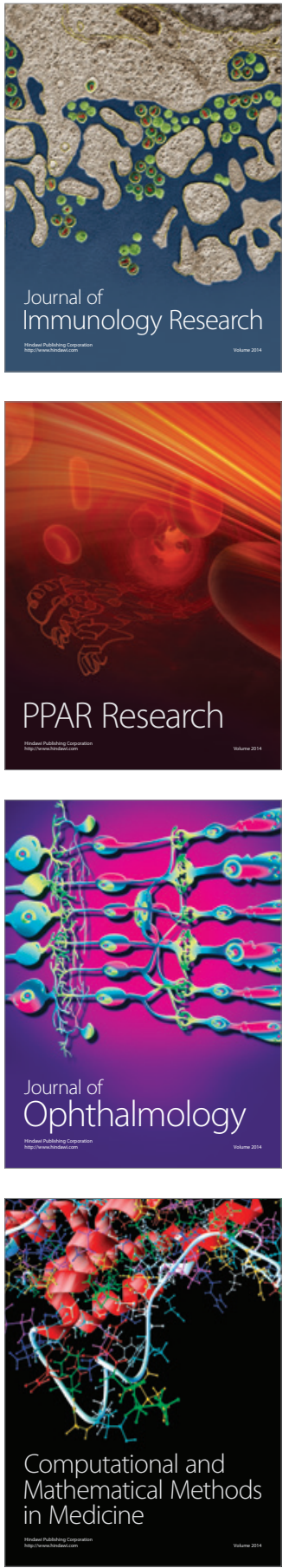

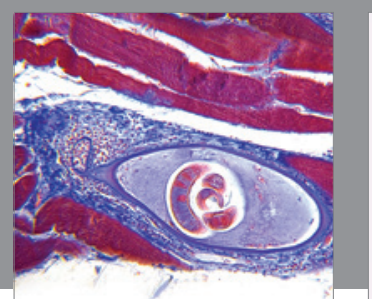

Gastroenterology Research and Practice

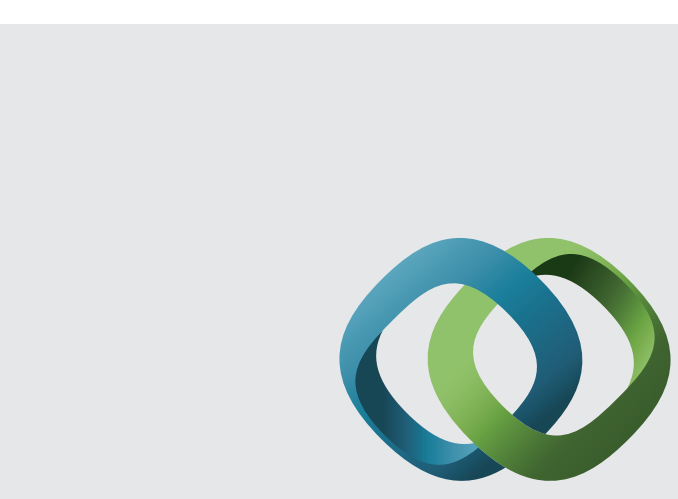

\section{Hindawi}

Submit your manuscripts at

http://www.hindawi.com
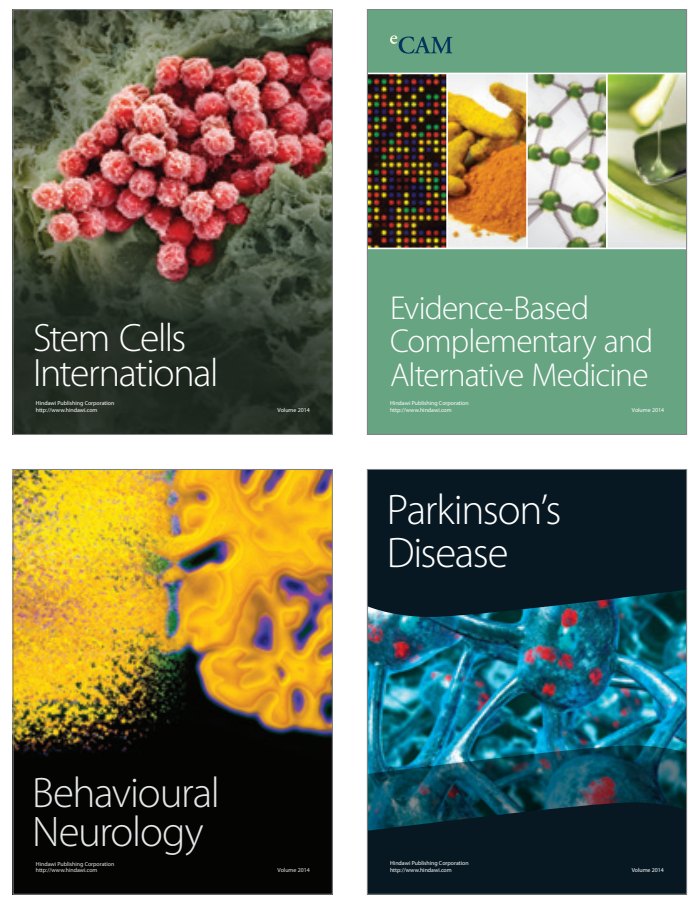
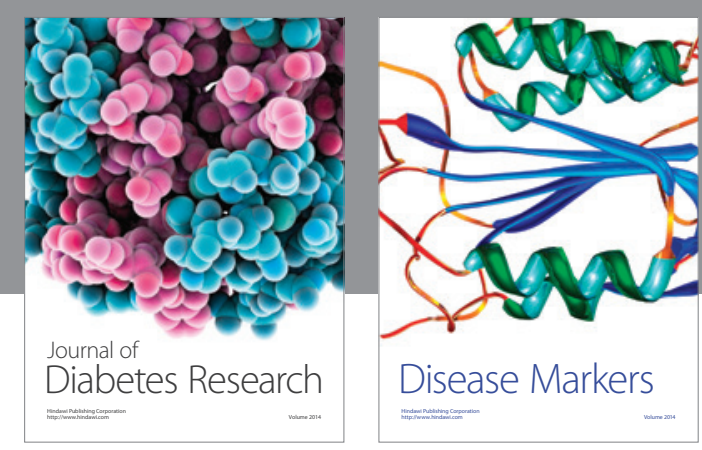

Disease Markers
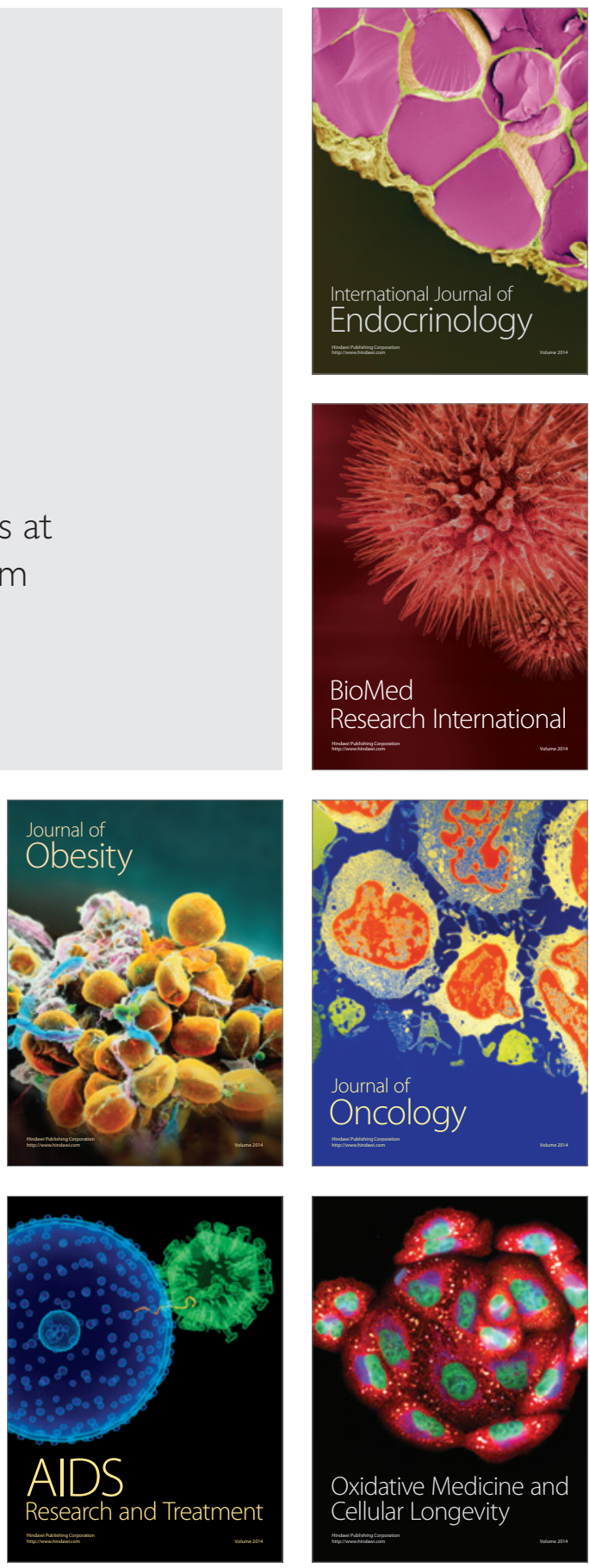